\title{
CONSUMER PERCEPTIONS OF SUPERMARKET SERVICE QUALITY: SCALE DEVELOPMENT AND VALIDATION
}

\author{
P F Venter and M Dhurup
}

Dept of Business Management, North-West University

\begin{abstract}
The retail industry remains one of the largest sectors in the global economy. In South Africa, retailing is one of the toughest and most competitive industries. The South African retail business environment is becoming increasingly hostile and unforgiving, with intense competition from both domestic and foreign companies (Terblanche, 1998: 1). The findings of this preliminary study do provide basic support for a three-factor structure for supermarket service quality in terms of reliability and validity. The reliability analysis, which followed the factor analysis, reflected coefficient á values ranging from 0.85 to 0.90 , indicating high internal consistency among variables within each dimension. In today's saturated retail markets, retailers face increasing hurdles to attract and maintain customers.
\end{abstract}

Keywords: Cronbach alpha, design, purification, reliability values, service quality, servqual, validation

JEL M21

\section{1}

\section{Introduction}

Supermarkets within the retail industry are renowned for their high level of competitive rivalry between various national chain stores. To address the unique needs of their customers and potential customers, management of supermarkets is continuously challenged with the task of having to differentiate their service offering from that which is provided by their competitors (Evangelidis, 1994: 5). Increased awareness of consumer rights has also led to greater expectations and demands by consumers.

In South Africa, supermarket retailing had a devastating effect on the traditional corner store. Chain store supermarkets have made great inroads in the retailing field in the last twenty years (Farquhar, 2002: 6). From an almost exclusive focus on satisfying the needs of the more affluent white consumer, retailers had to change their marketing strategies in order to bring black consumers into their stores. Driven by highly competitive management, the larger national chains are continuously fighting for market share and continue to apply pressure on smaller, independent retailers. Survival will depend on astute marketing, building of relationships and emphasising the quality of services in meeting the changing needs of the consumer (Sirohi et al., 1998: 223).

\section{2}

\section{Theoretical background}

There is general agreement that a basic retailing strategy for creating competitive advantage is the delivery of high service quality (Berry, 1986: 3-6; Hummel \& Savitt, 1988: 5; Reichheld \& Sasser, 1990: 103; Sui \& Cheng, 2001: 88).

For a merchandise retailer, competitive success is and will continue to be driven to a large extent by consumer perceptions of the quality of service. The demand for high-quality customer service is increasing as consumers have become more value conscious and seek a hassle-free shopping atmosphere (Lewison, 1995: 115). The modern shopper is more sophisticated and better informed than before 
and retailers have little option but to provide certain services at a competitive level if they want to appeal to the consumer (Samli et al., 1998: 28).

Definitions of service quality focus on meeting customers' needs and requirements, and how well the service delivered matches the customers' expectations. The most relevant approach in defining and measuring service quality is the user-based approach, i.e. from the customers' perspective (Woodruffe, 1995: 105) in which the human element forms an integral part in the rendering of service. Keltner and Finegold (1996: 57-58) assert that many service processes require active involvement of the consumer of the service and the consumer therefore becomes involved as a co-producer of the service. In seeking quality service, customer needs and expectations may differ.

\section{3}

\section{Measuring service quality}

Service quality is an elusive and abstract concept that is difficult to define and measure (Parasuraman et al., 1988: 21; Brown \& Swartz, 1989: 93; Carman, 1990: 33). Measuring service quality poses difficulties for service providers because of its unique characteristics: intangibility, heterogeneity, inseparability and perishability (Boshoff, 1990).

Furthermore, the improvement and measurement of service quality in retailing cannot be approached in the same way as that of a service perspective (Metha et al., 2000: 63). The uniqueness of services offered by a retailer makes the use of scales developed for other services questionable.

Although the ground-breaking SERVQUAL scale has been designed to measure service quality, it has been empirically tested in a number of studies involving "pure" service settings. It has not been successfully adapted to and validated in a retail environment that offers a mix of merchandise and services such as departmental stores, hypermarkets and supermarkets (Dabholkar et al., 1996: 6). A considerable variation in empirical factor structure has been reported in literature, which hampers our understanding of service quality and therefore casts doubts on the wide applicability and use of the SERVQUAL scale (Boshoff, 1997: 124). It also seems that more research still needs to be done concerning the dimensionality of service quality in general as called by researchers of the SERVQUAL scale (Parasuraman et al., 1994: 122).

The problem addressed in this study is a need to better understand the attributes that are important to consumers in their evaluation of supermarket service quality. The study focused on the following central research questions:

- What dimensions do consumers use to evaluate supermarket service quality?

- What relationships can be observed between the proposed service quality dimensions and future store patronage?

- What relationships can be observed between the proposed service quality dimensions and overall service quality?

\section{4}

\section{Research objectives}

The main purpose of this study is to develop a multi-dimensional scale that can be applied to measure consumers' perception of service quality in supermarkets.

\subsection{Specific objectives of the study are to:}

- establish the reliability and validity of the service quality scale,

- analyse the factor structure and dimensionality emanating from the study,

- evaluate the relationship between the proposed service quality dimensions on future store patronage, and

- evaluate the relationship between service quality dimensions on overall service quality. 


\section{5 \\ Research design}

Empirical studies were undertaken in two phases. Firstly, qualitative research was undertaken in the form of focus group interviews. Zeithaml's and Bitner's guidelines (1996) for critical incidents technique (CIT) were used to solicit responses (both positive and negative) from supermarket consumers. They were then paraphrased and condensed further into themes, which were then utilised in the scale construction. Secondly, two pilot studies were undertaken with sample sizes of seventy-five and seventy to purify the measuring instrument. The general procedure used by various researchers (Churchill, 1979: 64; Parasuraman et al., 1988: 14; Avkiran et al., 1994: 12; Baber, 1992: 43; Phillip \& Stewart, 1999: 179; Sureshchander et al., 2002: 24) served as a framework in developing the customer service quality instrument. The steps are summarised below:

- Establish dimensions of service quality through review of literature by identifying critical dimensions of the construct.

- Generations of items by careful selection of representative items through qualitative research.

- Develop instrument and pre-test the instrument.

- Scale purification through pilot testing.

- Collect fresh data from a new sample on a set of items that emerged from the previous stage.

- Purify the instrument through factor analysis, item modification, remove items which affect unidimensionality, remove items which affect internal consistency

- Evaluate reliability, dimensionality and validity of the instrument.

The final sample consisted of 607 respondents.

The nature of this study necessitated the use of a combination of convenience and judgement sampling (Parasuraman et al., 1991: 436; Nauman \& Giel, 1995: 201; Churchill, 1995: 454; Meidan, 1996: 53). The survey method was used to obtain relevant data to evaluate the scale and the factor structure. Care was taken to randomise the data collection. The population comprised individuals, both male and female, eighteen years and over, who have shopped at the particular supermarket one or more times in the last two months. A completely random sample was difficult to obtain as some control had to be exercised due to the requirement that respondents should have visited the supermarket at least once in the last two months. The data were collected over a three-week period in April 2003. Data were gathered from personal interviews conducted at a well-known supermarket chain in a store intercept type situation. The particular chain of supermarket was chosen because of the high service element involved and it was large enough to permit research of this nature. In addition, the researcher was given permission and support from the management to conduct the research project. The supermarket chain appeared among the top thirty companies in South Africa over a five-year period from 1998 to 2002.

The table below reflects the sample composition among the three supermarkets.

Table 1

Sample size and composition

\begin{tabular}{|l|c|c|c|}
\hline Supermarket & Sample size & Male & Female \\
\hline Store A & 198 & 109 & 89 \\
\hline Store B & 201 & 116 & 85 \\
\hline Store C & 208 & 99 & 109 \\
\hline Total & 607 & 324 & 283 \\
\hline
\end{tabular}


A six-point likert scale was used ranging from strongly agree to strongly disagree with a category not applicable in the end. This category was added to pre-empt mid-point responses from customers having no experience of the items under consideration. In addition, the questionnaire contained a statement on overall service quality, intentions to shop, intentions to recommend the supermarket to a friend and complaints about poor service. Demographic information was collected which included marital status, age and income levels. The questionnaire made use of a perceptions-based measure of service quality in light of the suggestions put forward by various researchers (Cronin \& Taylor, 1992: 55; Carman, 1990: 46; Teas, 1993: 33; Vasquez et al., 2001: 6; Dabholkar et al. ,1996: 3; Boulding et al., 1993: 9., Kim \& Jin, 2002: 225) that consumers evaluate service quality mainly on perceptions. The response data were first analysed for reliability using Cronbach alpha. Multivariate statistics, namely factor analysis, were utilised to reduce the variables into identifiable factors.

\section{Results and analysis}

\subsection{Focus groups}

Focus group interviews were used as a preliminary data-gathering mechanism to generate variables for the pilot questionnaire. Groups were developed by initially establishing their experience in supermarkets. The main part of the interview involved a discussion of the aspects each participant perceived as being important in evaluating service quality in supermarkets. Each anecdote was numbered and summarised into a list of key words and phrases (paraphrased) which encapsulated the customers' experience of the service. To facilitate the discussion, the researcher recorded the main ideas. In addition, each group discussion was recorded. Following the discussion, the tapes were transcribed. The summaries of the paraphrases were then given to two independent researchers to evaluate the appropriateness of the paraphrases against the original anecdote. Some of the incidents exceeded thirty words, while the rest were just short comments on certain aspects of service quality. A total of ninety-three incidents were analysed, which comprised 47 per cent males and 53 per cent females.

\subsection{The pilot study}

A total of forty representative variables that were extracted during the qualitative phase were then administered via a structured questionnaire to seventy-five supermarket consumers. The standardised alpha for the scale was recorded at 0.8700 , exceeding the suggested level of 0.70 (Nunnally, 1978: 245). Factor analysis (varimax rotation) was then performed on the forty latent variables. Loadings of 0.30 and above (Churchill \& Iacobucci, 2002: 809) were retained. Factors were extracted with eigenvalues $>1$. Five factors were extracted. The reliability of the factors ranged from 0.7887 to 0.4111 . Item reduction was then undertaken due to the low reliability values on certain dimensions. Items with low factor loading and low item-to-total correlations were investigated. Three items were removed.

Upon making the adjustments, a further seventy supermarket consumers were interviewed using a thirty-seven item scale. Standardised alpha was recorded at 0.9481 . At the dimension level the Cronbach alpha ranged from 0.9116 to 0.6381 . Further item reduction as suggested by Aldlaigan and Buttle (2002: 369) was undertaken by examining low item correlations, multiple loadings and unstable variables and inter-item correlations. This resulted in the removal of four items from the scale.

The iterative process was re-run with thirtythree variables in the calculation of Cronbach alpha. Standardised alpha was recorded at 0.94257. Average inter-item correlation was 0.3405 indicating strong correlations among variables and data stability. Factor analysis (varimax rotation) showed greater clarity in terms of loading onto appropriate dimensions. At a dimension level Cronbach alpha ranged from 0.908 to 0.784 , demonstrating good internal consistency and reliability. However, some variables required closer scrutiny. A 
further two variables were removed as they showed instability and, in doing so, resulted in the improvement of the reliability values.

Cronbach alpha and factor analysis (principal components-varimax rotation) were computed to establish reliability and a factor structure. A thirty-one-item scale comprising five dimensions was established through several iterations. The standardised alpha for the scale was recorded at 0.941503 and at the dimension level the reliability ranged from 0.903764 to 0.784792 .

\subsection{The main study}

Against this background, the study was then extended to a sample of 607 supermarket consumers of a renowned supermarket chain in the Vaal Triangle region to establish the scales reliability, validity and robustness of the factor structure on a larger sample size. Prior to factor analysis, the appropriateness of factorability on the data set was established. The correlation matrix, i.e. strength of linear association among variables, was examined. Initial examination of the correlation matrix revealed that a substantial number ( 90 per cent) of the correlations were $>0.30$, which according to Avkiran (1994: 14) indicates factorability.

Furthermore, the Bartletts Test of Spericity was 8246.8000 at an observed significance level of 0.000 , allowing rejection of the hypothesis that the population correlation matrix is an identity matrix, i.e. with zero correlations. The Kaiser-Meyer Olkin (KMO) measure of sampling adequacy (MSA) was 0.9560, which is considered "marvelous" by Kaiser (1974: 35). In the final sample a clearer factor structure emerged as a result of several iterations, which resulted in the extraction of three factors with 30 variables. The computation of the Cronbach alpha and final factor structure are reflected in table 2. A complete factor structure and loading within each factor is reflected in annexure A.

Table 2

Reliability values

\begin{tabular}{|l|c|c|c|c|c|}
\hline Factors & $\begin{array}{c}\text { Cronbach alpha } \\
\mathbf{( 4 0} \text { variables })\end{array}$ & $\begin{array}{c}\text { Cronbach alpha } \\
(\mathbf{3 7} \text { variables })\end{array}$ & $\begin{array}{c}\text { Cronbach alpha } \\
\mathbf{( 3 3} \text { variables })\end{array}$ & $\begin{array}{c}\text { Cronbach alpha } \\
\mathbf{( 3 1} \text { variables })\end{array}$ & $\begin{array}{c}\text { Cronbach alpha } \\
\mathbf{( 3 0} \text { variables }) \\
\text { main } \text { survey }\end{array}$ \\
\hline Factor 1 & 0.749618 & 0.881772 & 0.831784 & 0.869005 & 0.901176 \\
\hline Factor 2 & 0.770040 & 0.912880 & 0.883854 & 0.903764 & 0.889985 \\
\hline Factor 3 & 0.788716 & 0.876834 & 0.784792 & 0.784792 & 0.854343 \\
\hline Factor 4 & 0.613799 & 0.815738 & 0.849175 & 0.843175 & - \\
\hline Factor 5 & 0.411118 & 0.638147 & 0.822968 & 0.838451 & - \\
\hline Overall alpha & 0.870000 & 0.948099 & 0.942536 & 0.941503 & 0.949685 \\
\hline $\mathrm{N}$ & 75 & 70 & 70 & 70 & 607 \\
\hline
\end{tabular}

In addition, the testing for response bias in the data collection procedure required the computation of separate coefficient á values for the first two-thirds and second one-third of the completed responses. It was hypothesised that the á values would not be significantly different from both groups (split samples) of responses.
The standardised á emerged as 0.9421 and 0.9481 respectively, inferring that the difference is too small to indicate that there were any significant differences in the data sets. The summary of the reliability values for the split samples is reflected in Table 3 below. 
Table 3

Reliability values - split sample

\begin{tabular}{|c|c|c|c|c|c|}
\hline No. of variables & Mean & Std. Dev. & $\begin{array}{c}\text { N } \\
\text { Alpha }\end{array}$ & $\begin{array}{c}\text { Standardised } \\
\text { inter-item } \\
\text { correlation }\end{array}$ & Average \\
\hline 30 & 46.38 & 13.34 & 204 & 0.9421 & 0.357 \\
\hline 30 & 54.66 & 16.17 & 402 & 0.9481 & 0.380 \\
\hline
\end{tabular}

Factor one labelled reliability, comprised ten variables and accounted for 40.9 per cent of the variance. This dimension incorporates the reliability and personal interaction aspects of the retail service quality scale of Dabholkar $e t$ al. (1996: 7). The items that loaded onto this factor relate mainly to the human element aspects of service delivery. The above conclusions are also in keeping with comments from focus group interviews where participants regarded proper complaints handling, short waiting time at cashiers, staff friendliness, courtesy, personal interaction and merchandise availability as important in improving services. Comments from participants, for example "To date nobody telephoned me back. Since then, I stopped shopping at this particular supermarket". "Many times I had to wait in long queues at the cashier", reiterate the view that customers place reliability as one of the key determinants in evaluating services.

The second factor labelled atmospherics, comprised ten variables and accounted for 5.89 per cent of the variance. This factor combines the tangible aspects of the SERVQUAL scale and the physical aspects of the retail service quality scale. This notion is also supported by the findings of focus group interviews. For example, some excerpts from the focus group interviews were: "In the fruit and vegetable section, you find leaves all over the floor and they do not even care to pick it up". "In the prepared food section of this supermarket, the assistants working with food did not wear hats. I found it dirty because hair can fall into the food served to customers". Consistent with literature on atmospherics, Bitner (1993: 57) reaffirms that store atmosphere and appearance are important in global evaluations of a retailer's service. Further insight and evidence from environmental psychology support the notion that atmospherics induced by store environment influence the attitude as well as the behaviour of the consumers (Donovan et al., 1994: 291). Kotler (2000: 527) are of the view that the environment offered by the store has an impact, influences the customers' decision to visit the store and also guides the consumers' inferences about service quality.

The third factor labelled policy, comprised ten variables and accounted for 4.41 per cent of the variance. This dimension captures aspects of service quality that are influenced by the supermarket's responsiveness to the needs of the customer. These findings support the qualitative studies undertaken. Participants in the focus groups, inter alia, referred to the following: "You cannot shop freely if you know that your car is not safe in the parking". "Whilst shopping, I found the shelf-packers are busy packing products on the shelves. I find it quite disturbing because we need space to move around with our trolleys".

Thus combining the conclusion obtained from literature review, exploratory research and the main survey, a structure with three basic dimensions is proposed (see Figure 1). 


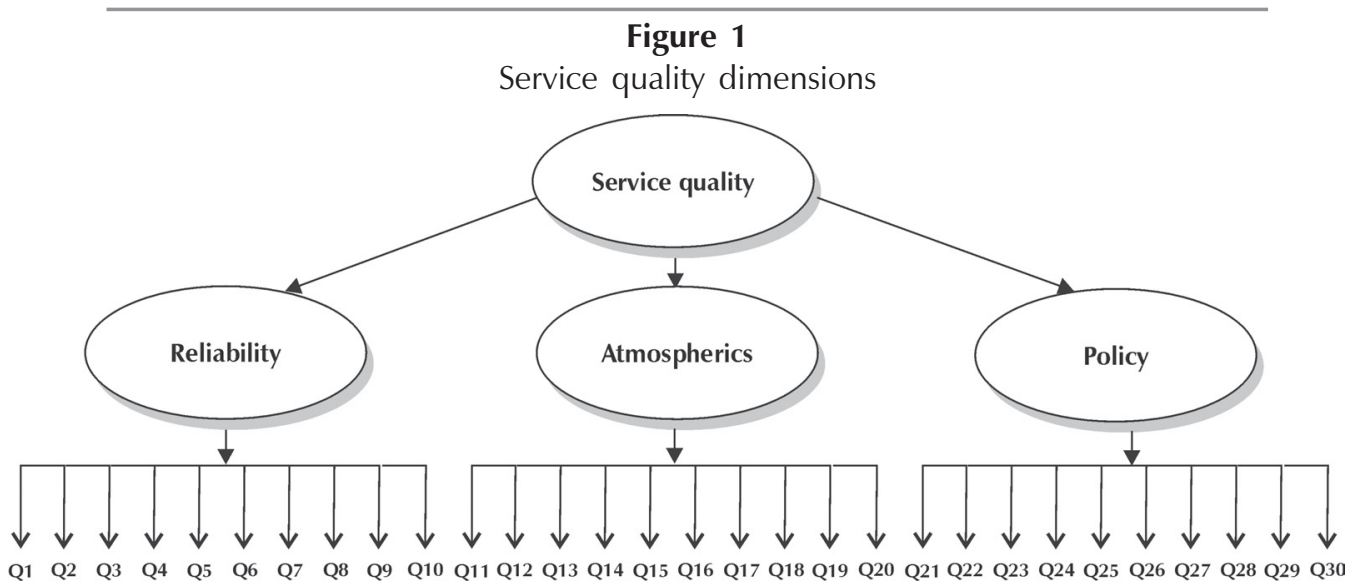

\section{7 \\ Validity}

To ensure that the service quality scale satisfies content validity, a mixed methodology research process was followed. Initially, a qualitative data collection process, namely focus group interviews, was undertaken to ascertain customer perceptions of supermarket service quality. The key ideas were then used in the questionnaire construction. Content validity was also ascertained by pre-testing the questionnaire and a review of the questionnaire by academics and practitioners in the field. The instrument was further purified during the various pilot-testing stages during which changes were made to the questionnaire.

The scale's convergent validity was assessed for statistical significance by using Pearson's correlation coefficients. The three dimensions of service quality, namely reliability, atmospherics and policy, were correlated with the overall measure of service quality (B1) of the questionnaire, i.e. overall, how would you rate the quality of service at the supermarket? Table 4 reflects that the marked correlations are all significant at $\mathrm{p}<0,05000$. This implies that the three dimensions of service quality do in fact converge with the measure of overall service quality. Furthermore, the reliability of a scale, as measured by coefficient alpha, reflects the degree of cohesion among scale items and is also an indirect indicator of convergent validity (Parasuraman et al., 1988: 12-35). The
Cronbach alpha values (refer to table 2) for the three dimensions are high in the study.

\section{Table 4}

Correlation of overall service quality and service quality dimensions

\begin{tabular}{|l|c|c|c|c|}
\hline Variable & B1 & Reliab & Atmos & Policy \\
\hline B1 & 1.00 & & & \\
\hline Reliabilty & $-0.49 *$ & 1.00 & & \\
\hline Atmospherics & $-0.53^{*}$ & $0.69 *$ & 1.00 & \\
\hline Policy & $-0.39 *$ & $0.73^{*}$ & $0.67 *$ & 1.00 \\
\hline
\end{tabular}

* Marked correlations are significant at $\mathrm{p}<0.05000$

Discriminant validity was measured by including an item in the study (B4) relating to complaints about poor services offered by the supermarket. The marked correlation in Table 5 depicts negative correlations between complaints about service rendered by the supermarket and overall service quality, thus providing evidence of discriminant validity.

Table 5

Correlation between complaints about poor services and service quality dimensions.

\begin{tabular}{|l|c|c|c|c|}
\hline Variable & B4 & Reliab & Atmos & Policy \\
\hline B4 & 1.00 & & & \\
\hline Reliabilty & $-0.43^{*}$ & 1.00 & & \\
\hline Atmospherics & $-0.35^{*}$ & $0.69^{*}$ & 1.00 & \\
\hline Policy & $-0.24^{*}$ & $0.75^{*}$ & $0.70^{*}$ & 1.00 \\
\hline
\end{tabular}

* Marked correlations are significant at $p<0.05000$ 
Table 6 reports on the results of the multiple regression analysis computed in order to establish the predictive power of the three service quality dimensions in assessing predictive validity. The three service quality dimensions were regressed with the following opinion data: overall service quality (B1), store patronage (B2) and recommendation of the supermarket to a friend (B3). Of the three dimensions, reliability and atmospherics seem to have greater impact on overall service quality than store patronage and recommendation of the store to a friend. Policy turns out to be a poor predictor in this regard. According to the beta coefficients, atmospherics as a dimension makes the largest impact across the three equations and reliability is the second-largest predictor of service quality. These findings are also in line with the results of some earlier studies that have highlighted the importance of soft issues (for example, the physical aspects of the store, complaints handling, trust, politeness) in improving service quality (Sureshchander $e t$ al., 2002: 69; Powel, 1995: 15).

Table 6

Regression analysis

\begin{tabular}{|c|c|c|c|c|}
\hline Dimensions * & B & Beta & $\mathbf{T}$ & p-level \\
\hline Reliability & 0.2949 & 0.2980 & 5.4127 & $0.0000^{*}$ \\
\hline Atmospherics & 0.3945 & 0.5024 & 7.8090 & $0.0000^{*}$ \\
\hline Policy & -0.1024 & -0.1142 & -1.8337 & 0.0719 \\
\hline \multicolumn{5}{|c|}{$R=0.5570 R^{2}=0.3103 \quad$ Adjusted $R^{2}=0.3069 F=3.603 * p<0.0000$} \\
\hline Dimensions $* *$ & B & Beta & $\mathbf{T}$ & p-level \\
\hline Reliability & 0.2067 & 0.23056 & 4.7417 & $0.0000^{*}$ \\
\hline Atmospherics & 0.3092 & 0.4432 & 5.6181 & $0.0000^{*}$ \\
\hline Policy & -0.0558 & -0.0687 & -0.9210 & 0.3573 \\
\hline \multicolumn{5}{|c|}{$R=0.4320 R^{2}=0.1866 \quad$ Adjusted $R^{2}=0.1826 F=3.603{ }^{*} p<0.0000$} \\
\hline Dimensions $* * *$ & B & Beta & $\mathbf{T}$ & p-level \\
\hline Reliability & 0.1776 & 0.1971 & 3.0599 & $0.0000^{*}$ \\
\hline Atmospherics & 0.3505 & 0.4901 & 6.5115 & $0.0000^{*}$ \\
\hline Policy & -0.0305 & -0.0336 & -0.5304 & 0.5959 \\
\hline \multicolumn{5}{|c|}{$R=0.4656 R^{2}=0.2168$ Adjusted $R^{2}=0.2129 F=3.603 * p<0.0000$} \\
\hline
\end{tabular}

* Service quality dimensions regressed with overall rating of service

** Service quality dimensions regressed with store patronage

*** Service quality dimensions regressed with store recommendations

8

\section{Customer profiles and service quality perceptions}

Sui (2001: 91) posits the view that there is a need to examine the demographic characteristics of customers when evaluating service in non-professional services such as retailing. The socio-demographic data were used to examine their association with the identified factors. Table 7 reflects the socio-demographic variables in relation to the identified factors. From the table it is evident that gender is not significantly related to reliability, atmospheric and policy variables. This implies that the three factors that emerged from the study are not in any way influenced by the gender categories. However, marital status is significantly related to the reliability factor, implying that married and single consumers view the various reliability aspects of service quality differently. Age, on the other hand, is significantly related 
to all three dimensions, implying that age plays a role in establishing service quality perceptions. The study reveals that income levels are significantly related to reliability and policy aspects in shaping consumers' perceptions of the quality of services offered by supermarkets.

Table 7

Analysis of variance: demographic variables and service quality

\begin{tabular}{|l|c|cc|cc|cc|}
\hline \multirow{2}{*}{ Variables } & df & \multicolumn{2}{|c|}{ Reliability } & \multicolumn{2}{c|}{ Atmospherics } & \multicolumn{2}{c|}{ Policy } \\
& & F & P & F & P & F & P \\
\hline Gender & $1: 605$ & 1.087 & 0.2975 & 1.072 & 0.3008 & 0.702 & 0.4024 \\
\hline Marital status & $4: 602$ & $2.510^{*}$ & 0.0408 & 1.614 & 0.1691 & 1.378 & 0.2400 \\
\hline Age & $5: 601$ & $6.964^{*}$ & 0.0000 & $3.351^{*}$ & 0.0054 & $4.406^{*}$ & 0.0006 \\
\hline Income & $5: 580$ & $6.579 *$ & 0.0000 & 1.027 & 0.4009 & $3.555^{*}$ & 0.0035 \\
\hline
\end{tabular}

* significant at $\mathrm{p}<0.0500$

9

\section{Recommendations, limitations and implications for future research}

The supermarket chain in the study is a renowned retailer in South Africa. Its consistent service image has proved to be a success in its retail operations in South Africa. The study demonstrated that customers attach great importance to the atmospheric variable (physical aspects), the reliability and the policies of the retailer. For supermarkets to establish or enhance service quality, they have to ensure that staff members are polite and courteous to customers, have the knowledge to answer customer questions and handle complaints effectively and promptly. Atmospherics and reliability seem to be strong predictors of overall service quality, store patronage and recommendation of the supermarket to friends. Managements of supermarkets should place greater emphasis on the atmospheric and reliability variables in order to enhance service quality perception among consumers. While the retailer's policy may not seem to be a strong predictor of overall service quality, store patronage and recommendations of the store to friends, its value should not be underestimated.

Store policies must be responsive to the needs of the customer. Store policies, such as in-house cash withdrawal facilities, payment of utility bills and safe customer parking, are essential ingredients of enhanced service quality and customer satisfaction. The role of technology should not be underestimated. New technology and interactive marketing can create new opportunities for supermarkets. Retailers can use technology to simplify and improve the services offered to customers. Routine and repetitious tasks can be handled by a system, freeing employees to deal with more important customer requests and problems.

This study, undertaken within the supermarket setting, adds to the growing literature calling for the re-examination of how to measure and manage service quality. The results of this study cannot be accepted as being completely relevant and applicable to all retailers who offer a mix of goods and services because of the limited sample size, the sampling procedure and particularly its focus on supermarkets.

The instrument has been validated by collecting data from customers of a supermarket chain in a developing country (South Africa). There is a possibility that perceptions of customers from other developed countries may vary.

This study has identified categories that are important to customer perceptions of service quality in supermarkets. However, it also raises a number of issues outlined below that could benefit from future research.

The interpersonal category (the human element) recorded a number of incidents in the focus group interviews. There would be value in additional work to analyse these incidents 
further to try to establish a more detailed perspective on the key influencing factors.

Previous research (Stafford \& Enis, 1969: 457; Monroe, 1973: 75; Sproles, 1977: 63-77; Parasuraman et al., 1985: 41-50; Zeithaml, 1988: 11; Boshoff, 1990: 87; Dodds \& Monroe, 1991: 315; Injazz et al., 1994: 26) has shown that price is often not an indicator of quality. Should supermarkets continue to emphasise low prices in their competitive strategies or should they accept the risk of asking customers to pay a premium for enhanced services?

The sample was more representative of the white target market of the supermarket chain. Some other possibilities for future consideration could include cross-cultural comparison of the different cultural groups. Cross-cultural comparison of service quality perceptions may provide rewarding research in South Africa. Do different cultural groups have different perspectives of service quality in supermarkets?

10

\section{Conclusion}

The findings of this preliminary study provide basic support of a three-factor structure for supermarket service quality in terms of reliability and validity. The five dimensions conceptualised at the beginning of the study with forty variables were empirically reduced to thirty variables and emerged as three distinct and interpretable factors, namely reliability, atmospherics and policy. The reliability analysis, which followed the factor analysis, reflected coefficient á values ranging from 0.85 to 0.90 , indicating high internal consistency among variables within each dimension.

Although managements of supermarkets can pride themselves on many success areas as to service quality, with increasing competition efforts will have to be continuously focused on service excellence. Gerstner (cited in Schiff, 2001: 04) aptly sums up service quality in the competitive retail environment as "being best in class in service quality is not the result of any one person's effort - it comes from leadership, focus and passion at every level of the organization ".

A comprehensive instrument framework has been proposed which can be used to measure and understand customer perceptions of service quality in a supermarket context. It is hoped that the findings of the study will help to advance an archetype of service quality based on the identified three dimensions in order to better comprehend the concept of service quality and its constituents.

Annexure A

Empirical factor structure*

\begin{tabular}{|l|l|l|l|l|}
\hline Items & Variable description & $\begin{array}{l}\text { Factor } \mathbf{1} \\
\text { loading }\end{array}$ & $\begin{array}{c}\text { Factor } \mathbf{2} \\
\text { loading }\end{array}$ & $\begin{array}{c}\text { Factor 3 } \\
\text { loading }\end{array}$ \\
\hline Q01 & Handling of customer complaints & 0.656227 & & \\
\hline Q02 & Waiting time at cashiers & 0.600444 & & \\
\hline Q03 & Provision for customer suggestions and comments & 0.532962 & & \\
\hline Q04 & Contact staff are polite to customers & 0.667524 & & \\
\hline Q05 & Safety in transacting with the store & 0.502843 & & \\
\hline Q06 & Willingness to help customers & 0.694613 & & \\
\hline Q07 & Knowledge to answer customer questions & 0.708557 & & \\
\hline Q08 & Respond to customer requests & 0.674576 & & \\
\hline Q09 & Employees give you personal attention & 0.696923 & & \\
\hline Q21 & Error-free sales transactions & 0.494265 & & \\
\hline
\end{tabular}




\begin{tabular}{|c|c|c|c|}
\hline Q22 & Employees are appropriately dressed & 0.597551 & \\
\hline Q23 & The fresh food display is always fresh & 0.573046 & \\
\hline Q24 & The store uses time-saving technology & 0.644694 & \\
\hline Q25 & $\begin{array}{l}\text { The store has modern-looking fittings and } \\
\text { equipment }\end{array}$ & 0.721088 & \\
\hline Q26 & The physical facilities are appealing & 0.680132 & \\
\hline Q27 & Clearly specified sales slips are given to customers & 0.718639 & \\
\hline Q28 & The brands sold at this store are trustworthy & 0.669626 & \\
\hline Q29 & A broad variety of brands are offered & 0.620241 & \\
\hline Q30 & The retailer's own brands are of a high quality & 0.608552 & \\
\hline Q31 & The store has convenient operating hours & 0.635372 & \\
\hline Q10 & Adequate till packers are available & & 0.518990 \\
\hline Q13 & Convenient cash withdrawal facilities are available & & 0.659225 \\
\hline Q14 & Merchandise is always available & & 0.599847 \\
\hline Q11 & Safe customer parking & & 0.415771 \\
\hline Q12 & Store layout enables customers to move around & & 0.547363 \\
\hline Q16 & The store is characterised by its pleasant aroma & & 0.615037 \\
\hline Q17 & Prices of products are clearly visible & & 0.541063 \\
\hline Q18 & $\begin{array}{l}\text { Layout makes it easy for customers to find } \\
\text { products needed }\end{array}$ & & 0.600439 \\
\hline Q19 & The retailer leads as a corporate citizen & & 0.581341 \\
\hline Q29 & The store provides good service at a reasonable cost & & 0.465614 \\
\hline
\end{tabular}

* Loading of 0.40 and more was considered significant

* Method of extraction - varimax rotation with Kaiser normalisation.

\section{References}

1 ALDLAiGAN, A.H. \& BUTTLE, F.A. (2002) "SYSTRA-SQ: A new measure of bank service quality", Industrial Journal of Service Industry Management, 13(3): 362-381.

2 AVKIRAN, N.K. (1994) "Developing an instrument to measure customer service quality in branch banking, International Journal of Bank Marketing, 12(6): 10-18

3 ANON. (2002) "Taking stock of retailing: A.C. Nielson's store census", Progressive Trends, 6: 16-17.

4 BABBER, sS. (1992) "A dynamic model for continuous improvement in the management of service quality", International Journal of Operations and Production Management, 12(2): 38-48.

5 BERRY, L.L. (1986) "Retail businesses are service businesses", Journal of Retailing, Spring, 62: 3-6.
6 BITNER, M.J. (1993) "SERVICESCAPES: The impact of physical surroundings on customers and employees", Journal of Marketing, 56: 57-71.

7 BOSHOFF, C. \& TERBLANCHE, N.S. (1997) "Measuring retail service quality: a replication study", South African Journal of Business Management, 28(4): 123-133.

8 BOSHOFF, H.C. (1990) "Perceptions of service quality in three selected service industries", Unpublished D.Com. Dissertation. Pretoria, University of Pretoria, Pretoria.

9 BOULDING, W.; KALRA, A.; STAELIN, R. \& ZEITHAML, V.A. (1993) "A dynamic process model of service quality: From expectations to behavioural intentions", Journal of Marketing Research, February, 30: 7-27.

10 BROWN, S.M. \& SWARTZ, T.A. 1989. "A gap analysis of professional service quality”, Journal of Marketing, April, 53: 92-98.

11 CARMAN, J.M. (1990) “Consumer perceptions of service quality: An assessment of the 
SERVQUAL dimensions", Journal of Retailing, 66: $33-55$

12 CHURCHILL, G.A. Jr. (1979) "A paradigm for developing better measures of marketing constructs", Journal of Marketing Research, February, 16: 64-73.

13 CHURCHILL, G.A. (Jr) \& IACOBUCCI, D. (2002) Marketing Research: Methodological Foundations, 8th ed. Harcourt College Publishers: FortWorth.

14 CHURCHILL, G.A. Jr. (1995) Marketing Research: Methodological Foundations, 6th ed. Dryden: Florida: 1117.

15 CRONIN, J.J. \& TAYLOR, S.A. (1992) "Measuring service quality: a re-examination and extension", Journal of Marketing, 56: 55-68.

16 DABHOLKAR, A.; THORPE, I.D. \& RENTZ, O.J. (1996) "A measure of service quality for retail stores: scale development and validation", Journal of the Academy of Marketing Science, 24(1): 3-16.

17 DODDS, W.B. \& MONROE, K.B. (1991) "Effects of price, brand and store information on buyers", Journal of Marketing Research, 28(1): 307-331.

18 DONOVAN, R.J.; ROSSITTER, J.; MARCOOLYN, G. \& NESDALE, A. (1994) "Store atmosphere and purchasing behaviour", Journal of Retailing, 70(3): 283-294.

19 EVANGELIDIS, A. (1994) "Customer perceptions of service quality at grocery supermarket outlets", Unpublished MBA. Dissertation. University of Witwatersrand, Johannesburg.

20 FARQUHAR, J. (2002) "A brief look at the history of South African Retailing", Progressive Trends, 6: 6-7.

21 GHOBADIAN, A.; SPELLER, S. \& JONES, M. (1994) "Service quality: Concepts and models", International Journal of Quality \& Reliability Management, 11(9): 43-66.

22 HUMMEL, J.W. \& SAVITT, R. (1988) "Integrated customer service and retail strategy", International Journal of Retailing, 3(2): 5-21.

23 INJAZZ, J.C.; ATUL, G. \& WALTERS, R. (1994) "A study of price and quality in service operations", International Journal of Service Quality Management, (2): 23-33.

24 KAISER, H.F. (1974) "An index of factorial simplicity", Psychometrika, 39(1): 31-36.

25 KELTNER, B. \& FINEGOLD, D. (1996) "Adding value in banking: human resources innovations for service firms", Sloan Management Review, Fall, 38(1): 57-67.

26 KIM, S. \& JIN, B. (2002) "Validating the retail service scale for US and Korean customers of discount stores: an exploratory study", Journal of Services Marketing, 16(3): 220-237.

27 KOTLER, P. (2000) Marketing Management, The Millennium Edition. $6^{\text {th }}$ ed. Prentice-Hall: Upper Saddle River, New Jersey.

28 LEWISON, D.M. (1997) Retailing, Prentice Hall: New Jersey: 883.

29 MEIDAN, A. 1996. Marketing Financial Services, Macmillan: Great Britain: 324.

30 METHA, C.; LALWANI, A.K. \& LI HAN, S. (2000) "Service quality in retailing: relative efficiency of alternative measurement scales for different product-service environments", International Journal of Retail \& Distribution Management, 28 (2): 62-72.

31 MONROE, K.B. (1973) "Buyers' subjective perception of price, Journal of Marketing Research, 10: 70-80.

32 NAUMAN, E \& GIEL, K. (1995) Customer Satisfaction Measurement and Management: Using the Voice of the Customer, Thompson Publishing: Cincinnati, Ohio.

33 NUNNALLY, J.C. (1978) Psychometric Theory $2^{\text {nd }}$ ed. McGraw-Hill: New York, .

34 PARASURAMAN, A.; ZEITHAML, V. \& BERRY, L.L. (1985). "A conceptual model of service quality and its implications for future research", Journal of Marketing, Fall, 49: 41-50.

35 PARASURAMAN, A.; ZEITHAML, V. \& BERRY, L. (1988) "SERVQUAL: A multipleitem scale for measuring consumer perceptions of service quality", Journal of Retailing, Spring, 64(1): 12-35.

36 PARASURAMAN, A.; ZEITHAML, V. \& BERRY, L. (1991) "Refinement and reassessment of the SERVQUAL scale", Journal of Retailing, Winter, 67(4): 420-450.

37 PARASURAMAN, A.; ZEITHAML, V.A. \& BERRY, L.L. (1994) "A reassessment of expectations as a comparative standard in measuring service quality. Implications for future research", Journal of Marketing, 58(1): 111-125.

38 PHILliP, G. \& STEWART, J. (1999) "Assessment of the service quality of a cancer information service using a new P-C-P attributes model", Managing Service Quality, 9(3):167-179.

39 POWELL, C.T. (1995) "Total quality management as competitive advantage: a review and empirical study", Strategic Management Journal, 16: 15-37. 
40 REICHHELD, F. \& SASSER, W.E. (1990) "Zero defections: Quality comes to service", Harvard Business Review, 68(5): 105-111.

41 SAMLI, A.C.; KELLY, J.P. \& HUNT, H.K. (1998) "Improving the retail performance by contrasting management and customer-perceived store images: A diagnostic tool for corrective action”, Journal of Business Research, 43 (1): 27-38.

42 SIROHI, A.; NIREN, S.; EDWARD, W.; MCLAUGHLIN, G. \& WITTINK, D.R. (1998) "A model of consumer perceptions and store loyalty intensions for a supermarket retailer", Journal of Retailing, 74(2): 223-245.

43 SPROLES, G.B. (1977) "New evidence on price and quality", Journal of Consumer Affairs, Summer, 11: 63-77.

44 SURESHCHANDER, G.S.; RAJENDRAN, C \& ANANTHARAMAN, R.N. (2002)

"Determinants of customer-perceived service quality: a confirmatory factor analysis approach", Journal of Services Marketing, 16(1): 9-34.

45 SCHIFF, L. (2001) "How customer satisfaction improvement works to fuel business recovery", Journal of Organisational Excellence, 20(2): 3-18.
46 SIU, N.Y.M. \& CHEUNG, J.T.H. (2001) "A measure of retail service quality", Marketing Intelligence \& Planning, 19(2): 88-96.

47 STAFFORD, J.E. \& ENIS, B.M. (1969) "Pricequality relationships: An extension”, Journal of Marketing Research, 6:456-459.

48 TEAS, K.R. (1993) "Expectations, performances evaluation and consumers' perceptions of quality", Journal of Marketing, 57: 18:34.

49 TERBLANCHE, N. (1998) Retail Management, Thomson Publishing Co: Johannesburg: 404.

50 VAZQUEZ, R.; IGNACIO, A.; DELBOSTIQUE, R.; DIAZ, A.M. \& RUIZ, A.V. (2001) "Service quality in supermarket retailing: identifying critical service experiences", Journal of Retailing and Consumer Services, 8: 1-14.

51 WOODRUFF, H. (1995) Services Marketing, Pitman Publishing: London.

52 ZEITHAML, V.A. (1988) “Consumer perceptions of price, quality and value: A meansend model and synthesis of evidence", Journal of Marketing, 52: 2-22.

53 ZEITHAML, V.A. \& BITNER, M.J. (1996) Services Marketing, McGraw-Hill: New York. 